\title{
EVALUATION OF CUP PROFILE FOR POSTHARVEST IN COFFEE VARIETY CASTILLO FROM CAUCA DEPARTMENT
}

\author{
A PREPRINT
}

\author{
Andrés Felipe Solis Pino* \\ Grupo IDIS \\ Universidad del Cauca \\ Popayán, Colombia \\ afsolis@unicauca.edu.co \\ Bibiana Montoya \\ Cadenas de Valor \\ Corporación Universitaria Comfacauca \\ Popayán, Colombia \\ bmontoya@unicomfacauca.edu.co
}

\author{
Carlos Andres Anacona Bambague \\ Cadenas de Valor \\ Corporación Universitaria Comfacauca \\ Popayán, Colombia \\ carlosbambague@unicomfacauca.edu.co
}

\author{
Efren Venancio Ramos Cabrera \\ Cadenas de Valor \\ Corporación Universitaria Comfacauca \\ Popayán, Colombia \\ eramos@unicomfacauca.edu.co
}

February 22, 2021

\begin{abstract}
It is widely accepted that the post-harvest processes of coffee are key factors in determining the final quality of the product. In the department of Cauca in Colombia, this stage is carried out empirically by the farmers of the region, using old methods that do not assure consistent quality. We propose a study to determine the best conditions of temperature and time in post-harvest for the coffee produced in the region. For this purpose, we carried the fermentation and honey process out on different samples of coffee of the Coffea Arabica species of the Castillo variety. Subsequently, the quality of the samples was determined through sensory evaluation by experts. Finally, descriptive statistical techniques applied to the resulting data, and component and hierarchical cluster analysis to find similarities between the samples. The results suggest that the honey process gets better evaluations in the cup profile over any fermentation condition.
\end{abstract}

Keywords Fermentation $\cdot$ Honey processes $\cdot$ Principal component analysis $\cdot$ Organoleptic properties

\section{Introduction}

The department of Cauca is one of the main producers of high-quality coffee in Colombia because of the particularities of its topography and climate, which is why it has become the fourth-largest producer of this bean at the national level [1]. The coffee produced in this region is especially appreciated by baristas and experts, thanks to its strong fragrance and aroma with caramel aspects, besides, when prepared in the cup its acidity is high, its body is medium and it has a balanced overall impression [2,3]. Likewise, this product has an important impact on the economy of Cauca, since about 95,000 families cultivate 93,000 hectares of the Arabica coffee plant, being the indigenous, peasants and Afro-descendant communities the largest producers [4], among the varieties produced the most prominent are Castillo, Colombia, Caturra and Borbon [5]. This allows inferring the primary value that coffee has in the department and its inhabitants, so it is of utmost importance to add value to the department's coffee production to improve the product.

In this sense, there have been multiple investigations that seek to improve the production process and the quality of coffee in the cup, mainly in recent times special importance has been given to the so-called semi-dry process, which

\footnotetext{
${ }^{*}$ Mechatronics engineer, master student in computer science, with special interest in software engineering and precision agriculture..
} 
A PREPRINT - FEBRUARY 22, 2021

is when the fermented coffee is dried without removing the remains of mucilage [6]. This process is fundamental because it is the most complex, effortful, and wasteful way to produce coffee, but if the activity is done well, it will cause a product rich in body and with an exceptional flavor [7]. This is the case of the research of Ladino-Garzón et al. in [8] where it is proposed to test the cup quality of samples of Caturra, Castillo, and f6 coffee from the south of the department of Huila, for this, it is fermented in water tanks at $0,12,18,18,24$ and 30 hours, subsequently, the quality of the resulting coffee is tested, using the method of the Specialty Coffee Association of America (SCAA, Specialty Coffee Association). Analysis of variance (ANOVA) was then used to determine the effect of fermentation time and variety on the final quality of the product. Finally, they concluded it valued the Castillo and F6 varieties as specialty coffees for all fermentation times, while the fermentation of the Caturra variety at 24 and 30 hours represented a decrease in the final quality of the product. Another related research is that of Louzada Pereira et al. [9], the authors state that the production of specialty coffees in the world is increasing because customers demand improvements in the quality and perception of this product. Therefore, they propose a study to test the sensory profile of Conilon coffee at different times $(24,48$, 48,72 , and 96 hours) of fermentation using Saccharomyces cerevisiae, to evaluate the modifications in the sensory profile of coffee. Finally, they conclude that the longer the fermentation time, the greater the increase in the overall score for coffee. Besides, they suggest that induced fermentations in Robusta species show a promising sensory profile, so they advise using these techniques in real production environments. Another important research in the area is that of Peñuela Martínez et al. in [10], in this it is mentioned that coffee mucilage fermentation in the Coffea Arabica species is a process whose outcome depends on multiple factors such as microorganisms growing in the environment, climate, fruit maturity, and bean variety. Therefore, the research tests the effect of the different wet fermentation processes and how these influences the quality of the coffee, and the concentration of organic acids. Two methodologies are used, in the first one the pulping time is delayed, and the normal coffee fermentation methods are changed, while the second method has to do with using a bioreactor to control the hydrogen potential $(\mathrm{PH})$ and the temperature of the fermentation mass, also, two control treatments were used for comparison. The results obtained suggest that the improvement in the quality of the coffee was obtained in those samples in which the fermentation times were short and at low temperatures, thus concluding that it is possible to improve the quality of coffee by introducing changes in the fermentation process of coffee production, thus achieving an improvement in the acidity and fragrance of the final product. Finally, the study by Ribeiro et al. [11], raises the inoculation of two strains of yeast in two varieties of coffee (Ouro Amarelo and Mundo Novo), the results suggest that the catalyst allowed improving the quality of the final product through sensory analysis.

However, studies have also been found that attempts to improve the quality of coffee in Cauca and Colombia through the use of technologies. This is the case of Solis et al. in [12], where vegetation indices are determined to measure chlorophyll in the Castillo variety, also in [13], they try to genetically improve the coffee plant or even in [14] new varieties are got. Although different research tries to improve the coffee produced in the department of Cauca, specifically in the Castillo variety, there is no evidence of studies that allow determining the ideal fermentation conditions (time and temperature) to improve the final product, for which reason there is a lack of knowledge in the production of a fundamental fruit for the region. Because of the above, many producers in Cauca associate empirical practices in the processing of coffee determining the time and temperature of the aerobic fermentation cycle based on the perceptions of touch, sensations, and sounds in the beans [15], which has resulted in not guaranteeing a homogeneous quality in its production, causing poorly processed coffee harvests and high production costs [16]. The above means a clear productive disadvantage concerning other regions, since market competitiveness privileges quality over other conditions, preferring thus, the added value that is determined by the sensory properties that describe the specialty in the cup profile [17].

Based on the above and having as its main concern to contribute to the improvement of the Cauca coffee production process, this research aims to determine the best conditions (temperature and fermentation time) in post-production for the coffee of the region, using a sensory analysis to determine the cup quality of the bean.

\section{Material and Methods}

Twenty-eight samples of coffee of the Coffea Arabica species of the Castillo variety in a state of complete ripening (divided into two cupping processes) were tested. The beans came from lot number three of the hacienda "Los Naranjos" of the Parque Tecnológico de innovación del Café (Tecnicafé), which is in the municipality of Cajibío in the department of Cauca, with geographical coordinates $2^{\circ} 35^{\prime} 11.6^{\prime \prime} \mathrm{N} \mathrm{y} 76^{\circ} 33^{\prime} 11.2^{\prime \prime} \mathrm{W}$, at an approximate altitude of 1862 Height above sea level and an estimated ambient temperature of $12^{\circ}$ to $18^{\circ}$ Celsius [18]. The harvested crop is of agrochemical production, under the shade with a staggering planting system, with a distance of 1.5 meters between the coffee trees, the approximate age of the trees is four and a half years since they're transplanting to the final site in the field. This coffee production lot has been given to the Corporación Universitaria Comfacauca, as a control lot to carry out diverse scientific research to improve coffee production in Cauca (Figure 1a). 
A PREPRINT - FEBRUARY 22, 2021

Table 1: Acronyms of the samples used in the study

\begin{tabular}{ll}
\hline \multicolumn{2}{c}{ Acronyms for samples used } \\
\hline Name & Acronym \\
\hline Cold temperature sample at 6 hours of fermentation & $6 \mathrm{~F}$ \\
Cold temperature sample at 12 hours of fermentation & $12 \mathrm{~F}$ \\
Cold temperature sample at 18 hours of fermentation & $18 \mathrm{~F}$ \\
Cold temperature sample at 24 hours of fermentation & $24 \mathrm{~F}$ \\
Ambient temperature sample at 6 hours of fermentation & $6 \mathrm{~A}$ \\
Ambient temperature sample at 12 hours of fermentation & $12 \mathrm{~A}$ \\
Ambient temperature sample at 18 hours of fermentation & $18 \mathrm{~A}$ \\
Ambient temperature sample at 24 hours of fermentation & $24 \mathrm{~A}$ \\
Hot temperature sample at 6 hours of fermentation & $6 \mathrm{C}$ \\
Hot temperature sample at 12 hours of fermentation & 12C \\
Hot temperature sample at 18 hours of fermentation & $18 \mathrm{C}$ \\
Hot temperature sample at 24 hours of fermentation & 24C \\
Sample honey washing process & HL \\
Sample unwashed honey process & HSL \\
Café denominación de origen Cauca & D.O.C \\
\hline
\end{tabular}

Subsequently, $50 \mathrm{~kg}$ of cherry coffee were taken and transported in refrigerated compartments to the processing plant in Supracafé [19], and were processed in a pulper of 2 (Figure 1b). They underwent semi-dry processing resulting in coffee in baba, which was stored in containers at different temperatures (see Table 1 for identification of the different samples). The first container of samples was stored at "cold temperature" with values between 10 and $16^{\circ} \mathrm{C}$, the second group of samples at "ambient temperature" with values between 17 and $23^{\circ} \mathrm{C}$, and finally, the third group of samples at "hot temperature" with values between 24 and $29^{\circ} \mathrm{C}$. The above temperature division is because the aim was to simulate the different temperature conditions of the different thermal floors of the department of Cauca. We subjected these specimens to aerobic fermentation by taking samples in triplicate at different times $(6,12,18$, and 24 hours). The mucilage was removed manually with clean water, ensuring the homogeneity of all samples. We carried the moisture loss process out by solar drying at Supracafé beneficiation station, reaching a humidity between 10 and $12 \%$, to fix microbial activity [20]. In parallel, we took samples to perform the coffee processing through the honey process without fermentation, to determine its cup profile and compare it with the semi-dry process. Subsequently, the coffee was threshed and classified by size in 14 mesh, followed by the physical analysis of the almonds, which is recommended by the National Federation of Coffee Growers of Colombia [17], to find possible physical defects in the samples. The cup quality tests were performed by a panel of 2 tasters who are experts in assessing the quality of coffee, following the method established by the SCA [21], besides, the rating values were calculated under the ISO 17025 procedure of Almacafé.

Finally, to determine the relationship between the sensory evaluations of the cup profiles, Principal Component Analysis (PCA) and Hierarchical clustering were used to determine the similarity between the samples.

\section{Results and Discussion}

In this section, the main results obtained during the research process on the cup profiles of Castillo variety coffee produced in the Cauca department are presented and analyzed using descriptive and inferential statistical techniques.

\subsection{Results of the cup profiles obtained for the Castillo variety of coffee from the Cauca department}

Based on the evaluation of the cup profile carried out in each of the cupping processes with different benefits (honey process and fermentation), it was found that all the samples analyzed varied between a score of 82 and 85 points, which translates into "very good" coffees by the SCAA [22]. The above allows determining that beyond the time and temperature scenarios to which the coffees were subjected, these are differentiated products by characteristics of origin, preparation, and sustainability in their production, reaffirming the quality of the coffee produced in the department of Cauca [23].

Figure 2 shows the different cup profiles for the honey and fermentation process. In this sense, it should be mentioned that the samples subjected to the honey process presented better results even above any specimen subjected to fermentation 


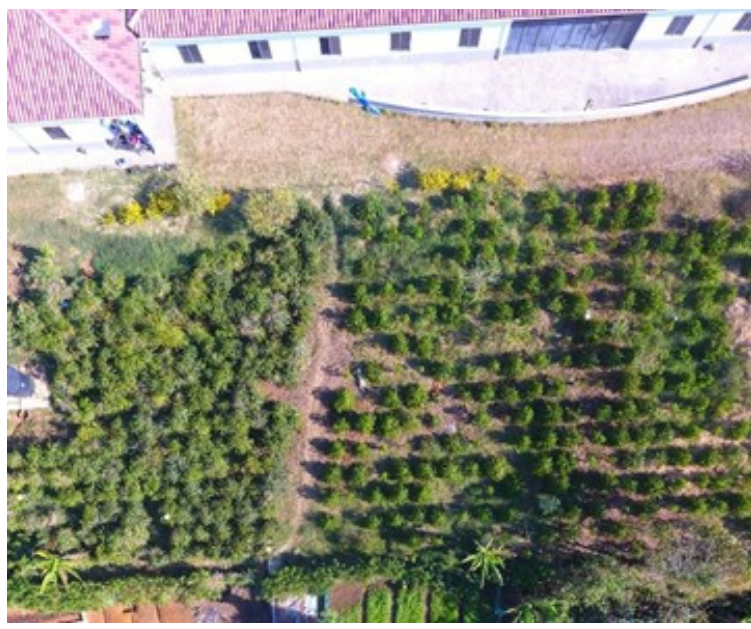

(a) Crop where the coffee samples were collected.

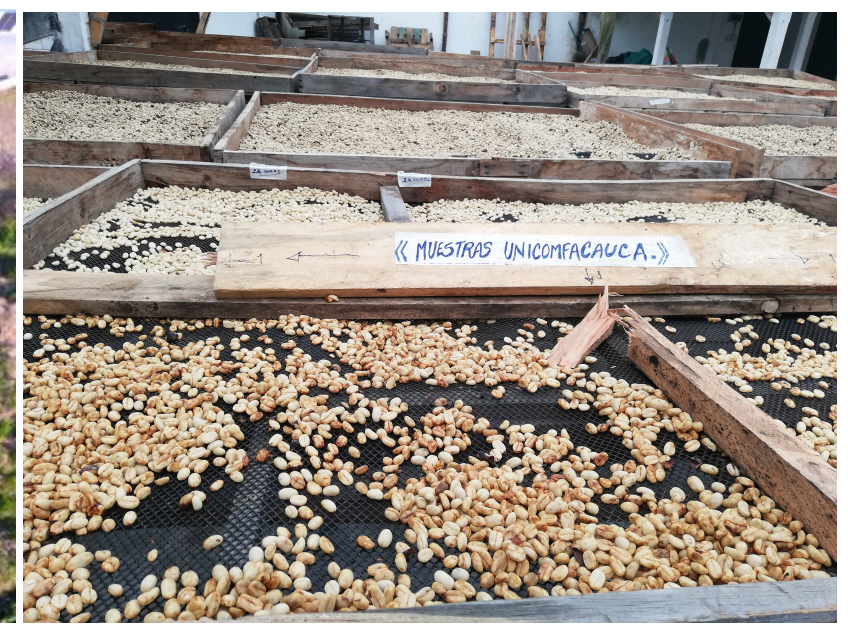

(b) Post-harvest coffee for fermentation tests and honey processing.

Figure 1: Coffee produced in the Cauca department of the species Coffea arabica.

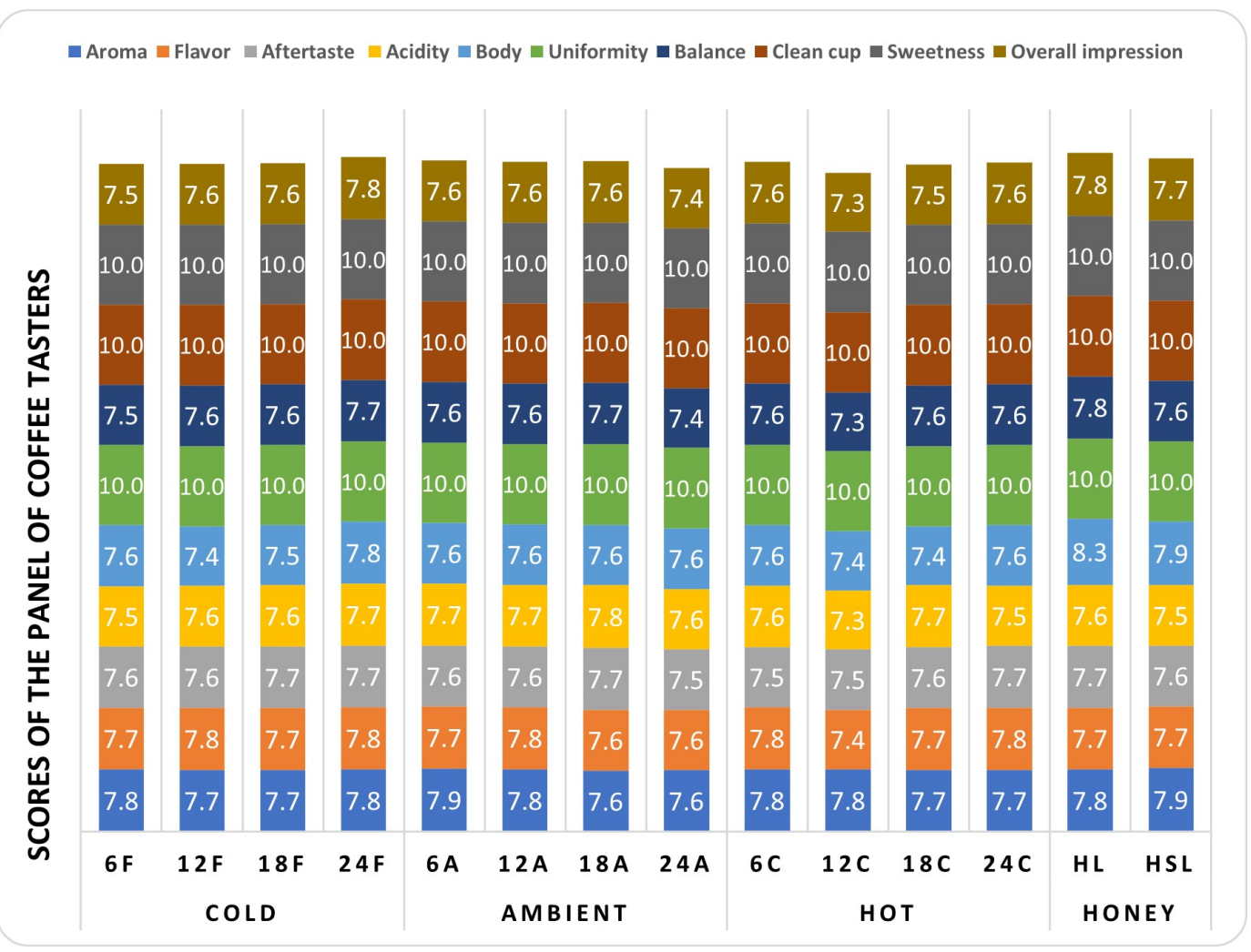

Figure 2: Average cup profile results performed using the SCAA protocol. 
A PREPRINT - FEBRUARY 22, 2021

under different conditions, this may be because in the absence of decomposing microorganisms sugars and other enzymes remain present in the grain, which translates into sweeter coffees and with a drier aftertaste and therefore better valued [24]. The almond coffee produced after honey processing gets a greater mixture of tannins, floral notes, and impregnated aromas that translate into better flavors when preparing the beverage, so it is widely accepted that the honey process should be used when seeking to find a balance of flavors, highlighting the best of washed coffee and natural coffee. The above results coincide with what has been found by other research, such as that of Burbano et al. in [25] and Boyacá Vásquez in [26], where they have tried to find which are the best processes to optimize the cup profiles of the Castillo variety in both the department of Huila and Boyacá, the inquiries yielded as the main result that the honey process offers the best organoleptic properties above the fermentation processes. Based on the previous results it can be mentioned that the coffee of the Castillo variety produced in the department of Cauca gets better cup profiles through the honey process, for which reason it is important to begin socialization campaigns by the coffee grower's federation to disseminate the honey process as a viable post-processing alternative to improve the quality of coffee production and in that order to get differentiated coffees.

On the other hand, it should be mentioned that fermentation plays a fundamental role in determining the cup quality of coffees. This is a natural process that occurs when the beans are harvested, and it groups the sugars and water. Fermentation can improve or detract from the quality of a coffee, but it is not the only determinant of flavor, since elements such as ambient temperature, ripening, and humidity of the fruit also play an important role in this decomposition process, so it is not a linear process [27]. Now, the results for fermentation at cold temperatures allowed determining that there is a progressive increase in the score got by the specimens as the degradation period passes, which is logical and confirms what has been consolidated by other research [28,29]. This happens because the microorganisms in charge of fermentation perform the decomposition more slowly [30], so substances such as sugar, ethanol, acetic acid, lactic acid, and carbon dioxide take longer to be released from the coffee bean [31]. Specifically, samples 24F, 6A, and $12 \mathrm{~A}$ were differentiated by being coffees with special, pleasant, and delicate flavors, constituting the specimens with the best evaluation of the cup profile in the fermentation process. The specimen 24A got a decrease in the evaluation of the cup profile with slightly vinegary and metallic flavors, which allows inferring that after the 18 hours of fermentation at ambient temperatures the cup quality of the coffee decreases, the above is in line with what was expressed by Ladino-Garzón et al. in [8], where it is appreciated that the Castillo variety coffee produced in the department of Huila presents a decrease in quality after 24 hours of fermentation with an approximate temperature of $22^{\circ} \mathrm{C}$, the same as for coffee produced in Cauca at ambient temperature. It should be mentioned that this is the range of temperatures at which the coffee growers of the region process their products, for which reason, according to the results found, in the department of Cauca in zones with temperatures between 17 and $23^{\circ} \mathrm{C}$ the semi-dry fermentation should be carried out with a maximum limit of 18 hours, to avoid the loss of differential characteristics in the cup profile. Finally, for the hot temperatures it was found that the results are on average lower than for the other two groups of samples, especially influenced by the $12 \mathrm{C}$ sample, which in the two cupping processes performed showed low values, this can be explained because the acidity and balance in these samples had low scores concerning the others, giving especially citric flavors with hints of bitterness.

\subsection{Principal component analysis}

A principal component analysis was carried out for the 10 organoleptic attributes measured in the coffee samples at different temperature and time conditions, two principal components were determined that present an eigenvalue greater than 1 and together explain approximately $81 \%$ of the total accumulated variance, the selection of these components is based on the Kaiser criterion [32]. We observed that the organoleptic properties with the greatest influence on CP1 are body, acidity, and overall impression with communality values greater than 0.86 aftertaste and aroma are poorly representative with communalities less than 0.68 .

Figure 3 shows that there are three large clusters of samples. The first group is formed by all the samples that were subjected to fermentation except for sample 24F, which suggests that these samples are similar in their organoleptic properties beyond the opposite conditions to which they were subjected, also, it can be mentioned that these samples present low results in the cup profile compared to other groups. The second conglomerate comprises the $24 \mathrm{~F}$ samples from the fermentation process and the washed and unwashed samples from the honey process; the samples in this group are the ones that present the best organoleptic properties, with special flavors with hints of slightly intense chocolate, red fruits, and a certain fruity acidity. Finally, the Cauca denomination of origin profile does not show similarity with any of the samples studied, this may be because the D.O.C. scores are an average of multiple samples analyzed from the entire department of Cauca, so it is not a measure for coffee produced in a single place. Therefore, it can allude that the denomination of origin should not be a comparative measure concerning the cup profile evaluations but should be a guide to guarantee a differentiated product according to the conditions that the geographical region where it was grown may have. 
A PREPRINT - FEBRUARY 22, 2021

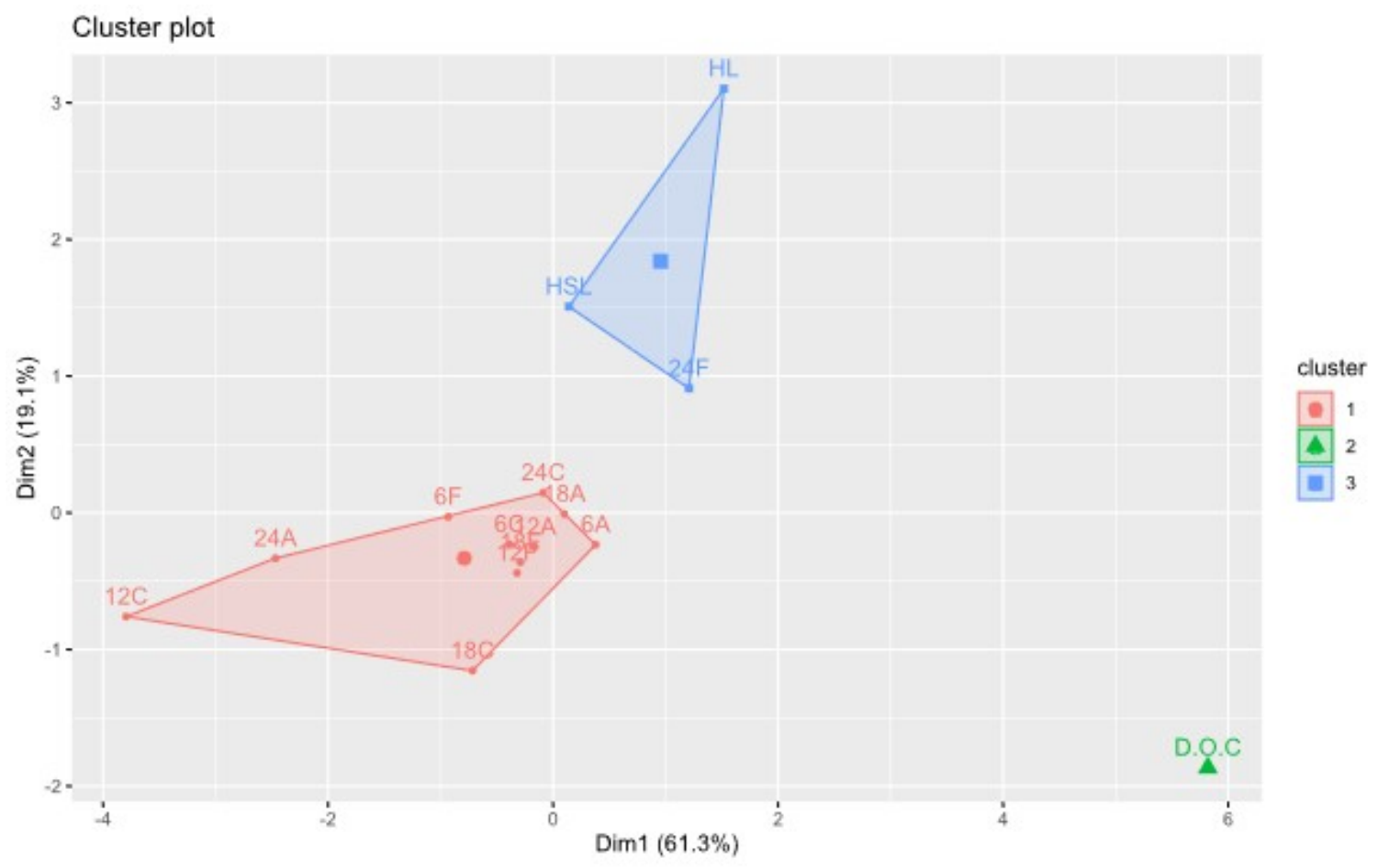

Figure 3: Grouping of samples according to their level of similarity for PCA analysis.

Concerning Figure 4 , we can infer that organoleptic properties such as body, overall impression, and aftertaste are related, so when one of these properties is well scored, the others also get good scores or inversely. A similar case occurs for flavor, balance, aroma, and acidity where it can be observed that they have a high degree of similarity. The previous figure also shows that the organoleptic properties are not inversely proportional to each other, therefore, it can be observed that all the coffee samples studied have varied characteristics and are not subordinated to a characteristic property.

Another analysis that allows us to perform the PCA is to determine under what circumstances the individuals studied are similar. Here, the individuals of conglomerate 2 are related by organoleptic properties such as body, cupping scores, and aftertaste, so it can be affirmed that the coffee processed under the conditions of these samples get similar characteristics in the mentioned organoleptic attributes, which translates into the fact that these types of samples get high scores in these properties. Specifically, the samples submitted to honey processing are related to a high evaluation in the organoleptic property of the body of the coffee, which shows that at the moment of evaluating these samples this property stands out above others and is characteristic of this type of samples, while for properties such as aroma and acidity there is certain independence so that if one wants to improve the general qualification in the cup, processes that enhance these properties should be carried out.

The samples of cluster 1, it was found that they are not significantly related to a specific property so that the coffees produced under these conditions do not have characteristics that stand out above the others. However, in samples 12C, $18 \mathrm{C}$, and $24 \mathrm{~A}$ it was found that the properties of cupping scores and aftertaste are indirect to these individuals, so it is inferred that their low cup profile score is because of these properties, since they rarely get high scores in cupping. Likewise, for individuals in cluster 1, it is sensed that to improve their cup average, organoleptic properties such as flavor, aftertaste, aroma, and acidity should be emphasized.

\subsection{Hierarchical clustering}

To identify the similarity between variables and individuals, we performed a hierarchical clustering analysis using the complete linkage clustering method and Euclidean distance, based on the AGNES clustering method. Previously, it was validated that there were no missing data, and we standardized the information to ensure its uniformity.

Figure 5 shows the dendrogram resulting from the hierarchical analysis performed, which allows us to get a series of important premises about the samples subjected to different processes and post-harvest conditions. Specifically, it can 
A PREPRINT - FEBRUARY 22, 2021

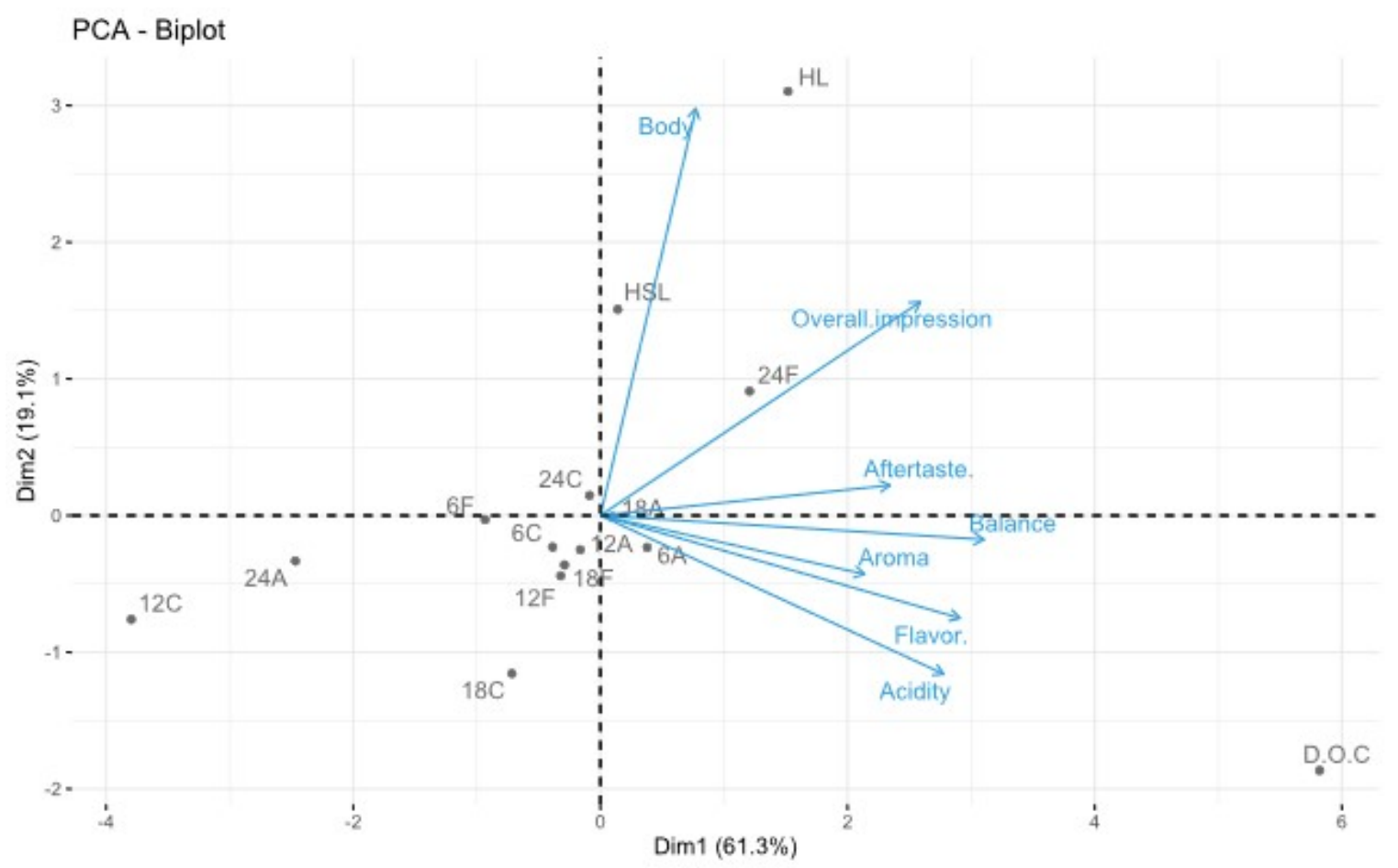

Figure 4: Biplot graphic of the PCA analysis for individuals and organoleptic properties evaluated according to cup profile.

be mentioned that the hierarchical analysis yielded results similar to the PCA, where it was found that the fermented samples (except sample 12C) have a similarity of approximately $85 \%$ among themselves, which shows that the time and temperature conditions during fermentation have an influence but to a lesser degree, while regarding the honey process samples their similarity is approximately $39 \%$, which allows inferring that the type of post-harvest processing influences the quality of the cup profile in the Castillo variety produced in the department of Cauca. Finally, it was found that the fermented samples and honey process samples do not have a relationship with the results of the D.O.C. profile.

We relate the groups formed in the hierarchical analysis to the clusters found in the component analysis, which reaffirms what was mentioned in the previous section. Specifically, the dendrogram reaffirms that the best cup scores for the fermented samples (24F, 6A and 12A) are similar, with a level of similarity of $92 \%$, which was also observable in the PCA evaluation where these samples are found at short distances. According to the above and considering the PCA analysis and the results of the cup profile, it can be inferred that the ideal conditions for fermenting coffee produced in Cauca of the Castillo variety is in cold temperatures at 24 hours and in ambient temperatures between 6 and 12 hours. Likewise, it can be noted that sample $12 \mathrm{C}$ has an approximate similarity of $80 \%$ with the rest of the fermented samples. This affirms what we previously expressed where it was mentioned that the balance and acidity for these samples negatively affected their cup scores.

\section{Acknowledgement}

We are grateful to the Corporación Universitaria Comfacauca for the financial and technical support received and to Tecnicafé for the logistical and technological support for the tests.

\section{References}

[1] Anderson Arenas-Clavijo and Inge Armbrecht. Gremios y diversidad de hormigas (Hymenoptera: Formicidae) en tres usos del suelo de un paisaje cafetero del Cauca-Colombia. Revista de BiologÃ $\backslash$-a Tropical, 66:48 - 57, 2018. Publisher: scielo. 


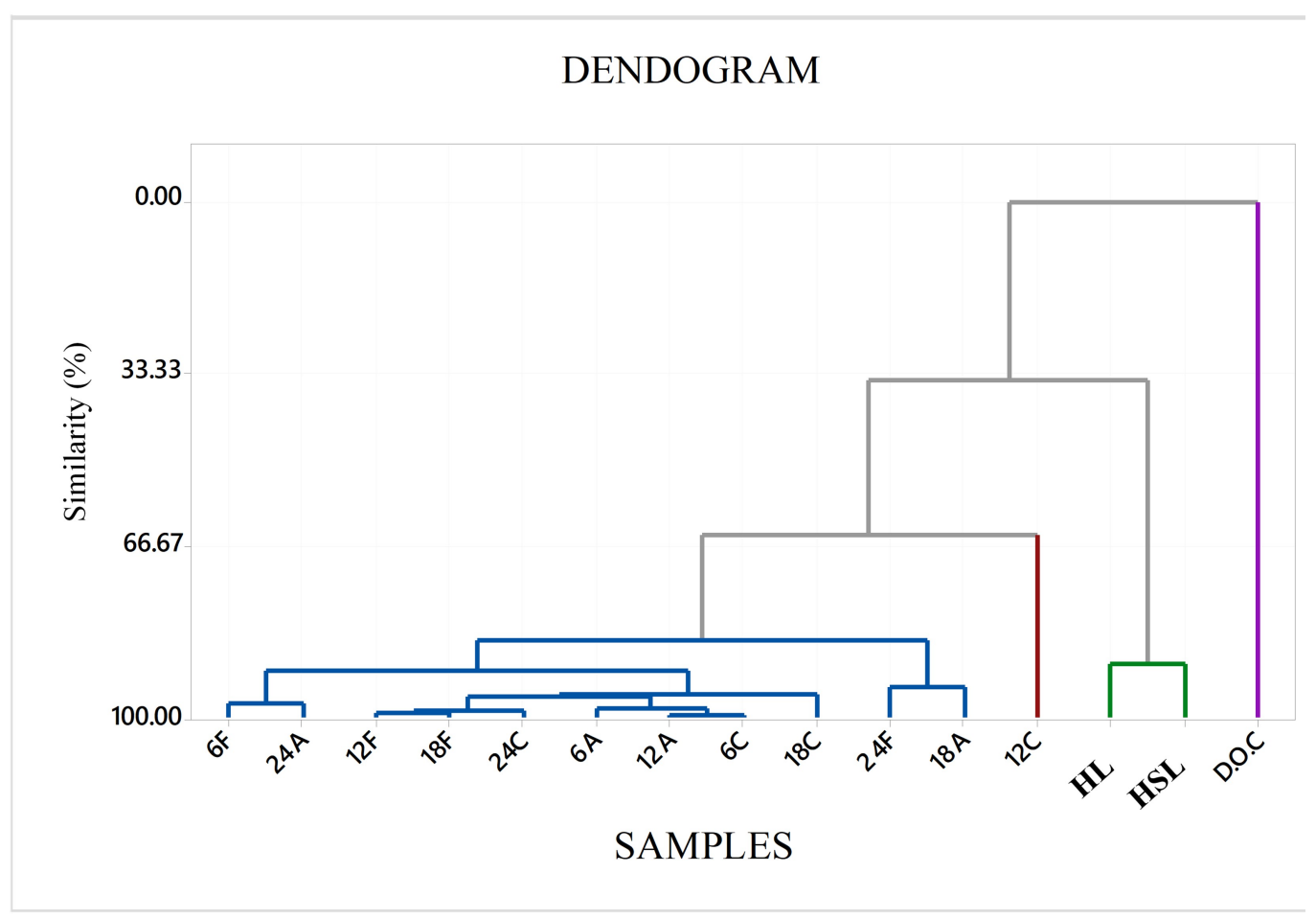

Figure 5: Dendrogram resulting from the hierarchical analysis performed for the samples evaluated by cup profiles.

[2] Diego Andrés Campo Ceballos and Carlos Alberto Gaviria López. Optimización de las condiciones de tiempo y temperatura en el proceso de tostado de café del cauca, teniendo en cuenta la percepción del consumidor. In Encuentro Internacional de Educación en Ingeniería 2019, Cartagena, Colombia, 2019.

[3] Andrés Villegas Hincapié, Huver Posada, Carolina Pérez Henao, Claudia Arboleda, and Luis Samper. Otros retos de la caficultura. Regionalización de la calidad del café de Colombia, Denominaciones de origen como estrategia de valor agregado. pages 181 - 208. 2013.

[4] Kevin Alexis Gómez Burbano. Diseño industrial del proceso de fabricación de madera aglomerada con base en los residuos de la producción de café en el municipio de Cajibío, Cauca. Encuentro Internacional de Educación en Ingeniería, August 2020.

[5] Ana Diaz Bohorquez, Nicholas Bayly, Jorge Botero, and Camila Gómez. Aves migratorias en agroecosistemas del norte de Latinoamérica, con énfasis en Colombia. Ornitologia Colombiana, 14:3-23, 2014.

[6] Giselle S. Duarte, Antônio A. Pereira, and Adriana Farah. Chlorogenic acids and other relevant compounds in Brazilian coffees processed by semi-dry and wet post-harvesting methods. Food Chemistry, 118(3):851-855, February 2010.

[7] Palmiro Poltronieri and Franca Rossi. Challenges in Specialty Coffee Processing and Quality Assurance. Challenges, 7(2):19, October 2016.

[8] Wilmer Ladino-Garzón, Erika T Cortés-Macías, Nelson Gutiérrez-Guzmán, and Claudia M Amorocho-Cruz. Calidad de taza de café (Coffea arabica L.) procesado en fermentación semi-seca. Agronomía Colombiana, 34(1):S281-S283, 2016.

[9] Lucas Louzada Pereira, Aldemar Polonini Moreli, Dério Brioschi Júnior, Luiz Henrique Bozzi Pimenta de Sousa, João Paulo Pereira Marcate, Gustavo Falquetto de Oliveira, Danieli Grancieri Debona, and Rogério Carvalho Guarçoni. CONSTRUÇÃO DE PERFIL SENSORIAL PARA O CAFÉ CONILON FERMENTADO. Revista Ifes Ciência, 5(2):242-252, 2019.

[10] Aida Esther Peñuela-Martínez, Arley David Zapata-Zapata, and Diego Luis Durango-Restrepo. Performance of different fermentation methods and the effect on coffee quality (Coffea arabica L.). Coffee Science - ISSN 1984-3909, 13(4):465 - 476, December 2018.

[11] Luciana Silva Ribeiro, Diego Egídio Ribeiro, Suzana Reis Evangelista, Maria Gabriela da Cruz Pedrozo Miguel, Ana Carla Marques Pinheiro, Flávio Meira Borém, and Rosane Freitas Schwan. Controlled fermentation of 
A PREPRINT - FEBRUARY 22, 2021

semi-dry coffee (Coffea arabica) using starter cultures: A sensory perspective. LWT - Food Science and Technology, 82:32-38, September 2017.

[12] Andrés Felipe Solis. Correlación del contenido de clorofila foliar de la especie Coffea arabica con índices espectrales en imágenes. Biotecnología en el Sector Agropecuario y Agroindustrial, pages 1-15, January 2021.

[13] J Castillo. Mejoramiento genético del café en Colombia. 50 años de Cenicafé. Conferencias Conmemorativas, 1990.

[14] Jaime Castillo Zapata and Germán Moreno Ruíz. Selección de cruzamientos derivados del Híbrido de Timor en la obtención de variedades mejoradas de café para Colombia. Cenicafé (Colombia) v. 32 (2) p. 37-53, 1981.

[15] SM Marín, J Arcila, EC Montoya, and CE Oliveros. Relación entre el estado de madurez del fruto del café y las características de beneficio rendimiento y calidad de la bebida. Cenicafé, 54(4):297-315, 2004.

[16] Canet Brenes, Armandocoord García, and others. Guía técnica para el beneficiado de café protegido bajo una indicación geográfica ó denominación de origen. Technical report, 2010.

[17] Alejandro Ospina Marulanda. La industria de los cafés de especialidad. Relación entre certificaciones de calidad o especialidad, y los ingresos de los caficultores en Colombia. 1989-2015. PhD Thesis, Universidad del Rosario, 2017.

[18] Zulma Katerine Ordoñez Fernández and Bibiana Patricia Montoya Bonilla. Evaluación agronómica de Coffea Arábica variedad castillo y caturra en dos sistemas de producción (sol y sombra); en la hacienda los naranjos, vereda la Venta (Cajibio-Cauca). ACCB, 1(29):Artículo Páginas 58-66, October 2017.

[19] David Camilo Corrales, Iván Darío López, Felipe Campo, Silvio Andrés Ordoñez, Juan Carlos Corrales, Apolinar Figueroa Casas, and Carlos León Roa. Plataforma para el seguimiento de variables meteorológicas y ambientales para el sector agropecuario. In en VII Congreso Ibérico de AgroIngeniería y Ciencias Hortícolas, Madrid, Madrid, Spain, 2013.

[20] Liang Wei Lee, Mun Wai Cheong, Philip Curran, Bin Yu, and Shao Quan Liu. Coffee fermentation and flavor An intricate and delicate relationship. Food Chemistry, 185:182-191, October 2015.

[21] Gilberto Vinícius de Melo Pereira, Ensei Neto, Vanete Thomaz Soccol, Adriane Bianchi Pedroni Medeiros, Adenise Lorenci Woiciechowski, and Carlos Ricardo Soccol. Conducting starter culture-controlled fermentations of coffee beans during on-farm wet processing: Growth, metabolic analyses and sensorial effects. Food Research International, 75:348-356, September 2015.

[22] Specialty Coffee Association of America. SCAA protocols-cupping specialty coffee. 2015.

[23] GI Puerta. Especificaciones de origen y buena calidad del café de Colombia. Technical report, Centro Nacional de Investigaciones de Café (Cenicafé), 2013.

[24] Víctor Manuel Martínez, Iván Darío Aristizábal, and Edilson León Moreno. Evaluation of the composition effect of harvested coffee in the organoleptic properties of coffee drink. Vitae, 24(1):47 - 58, 2017. Publisher: scieloco.

[25] Mileyi Burbano Jurado and Wilmar Iván Cabrera Artunduaga. Conocer el perfil de taza generado mediante la implementación de los métodos de cafés naturales, honey y cafés lavados con la variedad castillo general en los asociados a la Cooperativa Departamental de Caficultores del Huila-Cadefihuila del municipio de Acevedo-Huila. $\mathrm{PhD}$ thesis, Universidad Nacional Abierta y a Distancia de Colombia (UNAD), Huila, Colombia, 2018.

[26] Licett Andrea Boyacá Vásquez. Estudio exploratorio de la obtención de café verde mediante beneficio Honey y la determinación de su calidad en taza. Master's thesis, Universidad Nacional de Colombia - Sede Bogotá, Bogotá Colombia, 2018.

[27] GI Puerta. Calidad física del café de varias regiones de Colombia según altitud suelos y buenas prácticas de beneficio. Cenicafé, 67(1):7-40, 2016.

[28] Kênia Barbosa do Carmo, Jéssica Conceição Barbosa do Carmo, Marcelo Rodrigo Krause, and Guilherme Peterle. Sensory and physiological quality of arabic coffee under different fermentation times. Bioscience Journal, 36(2), 2020.

[29] Nataly Peña Gómez, Oscar Barrera Bermeo, and Nelson Gutiérrez Guzmán. Efectos del tiempo de fermentación sobre la calidad en taza del café (coffea arabica). Ingeniería y Región, 10:111-116, December 2013.

[30] Sylvie Avallone, Bernard Guyot, Jean-Marc Brillouet, Eugenia Olguin, and Joseph-Pierre Guiraud. Microbiological and Biochemical Study of Coffee Fermentation. Current Microbiology, 42(4):252-256, April 2001.

[31] GI Puerta. Factores procesos y controles en la fermentación del café. Technical report, Centro Nacional de Investigaciones de Café (Cenicafé), 2013.

[32] Henry F. Kaiser. Coefficient Alpha for a Principal Component and the Kaiser-Guttman Rule. Psychological Reports, 68(3):855-858, 1991. _eprint: https://doi.org/10.2466/pr0.1991.68.3.855. 